\title{
Communications
}

\section{Examens de spécialistes}

Examen de spécialiste en vue de l'obtention de la formation approfondie en pneumologie pédiatrique à adjoindre au titre de spécialiste en pédiatrie

Lieu: Ligue pulmonaire Suisse, Südbahnhofstrasse 14c, 3000 Berne 14

Date: jeudi, 30 août 2012

Délai d'inscription: 30 avril 2012

Vous trouverez de plus amples informations sur le site web de l'ISFM www.siwf.ch $\rightarrow$ formation postgraduée médecins-assistants $\rightarrow$ Examens de spécialiste

Examen de spécialiste en vue de l'obtention du titre de spécialiste en pneumologie

Lieu:

- Examen oral: Berne

- Examen écrit: Vienne (congrès ERS)

Date:

- Examen oral: jeudi, le 13 septembre 2012

- Examen écrit: Samedi, $1^{\text {er }}$ septembre 2012 (après-midi)

Délai d'inscription: le 30 avril 2012

Vous trouverez de plus amples informations sur le site web de l'ISFM www.siwf.ch $\rightarrow$ formation postgraduée médecins-assistants $\rightarrow$ Examens de spécialiste

Examen de spécialiste en vue de l'obtention du titre de spécialiste en endocrinologie/diabétologie

\section{Lieu: UniversitätsSpital Zürich}

Date: Vendredi, le 2 novembre 2012

- examen écrit: 8h30-12h30

- examens oraux: 14h00-17h00

Délai d'inscription: 10 septembre 2012

Vous trouverez de plus amples informations sur le site web de l'ISFM www.siwf.ch $\rightarrow$ formation postgraduée médecins-assistants $\rightarrow$ Examens de spécialiste

\section{Retrait de lot}

38 847, Liquémine 5000 U.I. sous-cutanée, seringues prêtes à $l^{\prime}$ emploi $25 \times 0,5 \mathrm{ml}$

\section{Produit: Lot 010211}

La société Drossapharm AG, 4002 Bâle, nous prie de communiquer ce qui suit:

Par mesure de précaution Drossapharm SA, en accord avec Swissmedic, rappelle le lot 010211 de Liquémine 5000 U.I., sous-cutanée, solution pour injection, seringues prêtes à l'emploi $25 \times 0,5 \mathrm{ml}$, qui se trouve sur le marché suisse.

Lors d'un contrôle de la documentation de lot de Liquémine chez le producteur contractuel externe, on a constaté que durant un cycle d'autoclavage du matériel d'emballage primaire vide (corps de seringue) il s'est produit un court influx d'air ambiant non classifié. Bien que le risque d'une contamination consécutive à cet événement soit extrêmement réduit, le lot concerné par cette déviation est retiré du marché à titre préventif.

Nous vous prions dès lors d'effectuer un contrôle de vos stocks et de retourner les produits du lot potentiellement concerné, avec la mention «Retrait de lot», à notre adresse de retours: Drossapharm AG, Birsweg 1, 4144 Arlesheim, tél. 0617051000.

Les autres lots de Liquémine 5000 U.I. souscutanée ainsi que les flacons de Liquémine 25000 U.I. ne sont pas concernés.

Vous trouverez les informations correspondantes sur le site Internet de Swissmedic.

Drossapharm AG, Bâle/Arlesheim

\section{Académie Suisse des Sciences Médicales}

Moyens issus du fonds Käthe ZinggSchwichtenberg: Ethique médicale et projets innovateurs

L'ASSM met à disposition des moyens issus de ce fonds pour soutenir des projets de recherche dans le domaine de l'éthique médicale ainsi que des aides au lancement de projets scientifiques innovateurs pour lesquels il n'existe pas encore d'institutions de soutien établies.

En 2012, la somme de 250000 francs sera attribuée.
Les candidatures concernant ces aides à la recherche devront être présentées en langue allemande, française ou anglaise. Un montant maximal de 60000 francs est octroyé par projet.

Les formulaires de demande peuvent être remplis et imprimés sur l'ordinateur (www. assm.ch $\rightarrow$ recherche).

Date limite d'envoi des demandes: 31 mars 2012.

\section{Société Suisse de Médecine Interne} Générale (SSMI)

\section{Prix SSMI 2012}

Le prix SSMI 2012, d'un montant de 10000 francs, sera attribué pour un travail scientifique original remplissant les conditions suivantes:

- Le travail doit avoir été publié dans une revue médicale, ou avoir été accepté par celle-ci en 2011, en vue de sa publication. Le thème du travail doit présenter un intérêt particulier pour la prise en charge de patients souffrant de maladies relevant de la médecine interne, ou ouvrir la voie à de nouvelles techniques diagnostiques ou thérapeutiques concernant ce type de -maladies. Des études rétrospectives peuvent être soumises, si elles concernent des domaines de la Médecine Interne Générale.

- Les auteurs suisses peuvent également présenter des travaux publiés (à publier), ou effectués, à l'étranger.

- Les auteurs étrangers ne peuvent présenter un travail que dans la mesure où il a été réalisé en Suisse, ou avec un groupe suisse.

Le travail doit être adressé en 5 exemplaires jusqu'au 23 mars 2012 au président de la -Société Suisse de Médecine Interne Générale: Prof. Dr méd. Jean-Michel Gaspoz, Société Suisse de Médecine Interne Générale, «Prix SSMI», case postale 422, 4008 Bâle. 


\section{Swiss Society for Infectious Diseases / Swiss Society of Hospital Hygiene}

\section{Awards 2012}

Swiss Society for Infectious Diseases (SSI) and Swiss Society of Hospital Hygiene (SSHH) will award three prizes in 2012, each in the amount of $15000 \mathrm{CHF}$, sponsored trough equal contributions by the Swiss Academic Foundation for Education in Infectious Diseases (SAFE-ID) and by the two societies.

\section{Eligibility}

- Authors of an outstanding scientific publication in basic, clinical or epidemiological research in infectious diseases.

- A significant part of the work must have been performed in Switzerland.

- The paper (or group of related papers) must have been either published or accepted for publication between June 15th, 2011 and April 15th, 2012 by an internationally renowned peer-reviewed journal.

\section{Conditions}

- Applications should be accompanied by a cover letter stating the name of the applicant and the prize category applied for. If the paper is accepted but not yet published please attach the letter of acceptance. All authors agree with the application.

- A Prize committee designated by the committee of the SSI and SSHH performs the evaluation. Decisions made by the committee are definitive and not subject to appeals.

- The award is given to the author of the publication at the annual meeting of the
SSI/SSHH in St. Gallen, June 21, 2012. The awardee is expected to give a short presentation of his work

- The award is intended to support a research project of the awardee.

- The award is publicized in the Swiss medical press, on the SSI and the SSHH websites and to the members of the SSI and SSHH.

- Deadline for applications: April 15th, 2012

Please submit the documents by e-mail to the president of the prize committee: Prof. Dr. med. Stephen Leib, Universität Bern, Institut für Infektionskrankheiten, Friedbühlstr. 51, 3010 Bern, Switzerland, E-Mail: stephen.leib[at] ifik.unibe.ch

\section{Caisse de secours des médecins suisses}

\section{Contributions reçues}

Du $1^{\text {er }}$ octobre au 31 décembre 2011, nous avons reçu 296 dons d'une valeur totale de 74378 francs.

Le Conseil de fondation de la Caisse de secours des médecins suisses est très content de pouvoir publier ces chiffres et tient à remercier vivement tous les donateurs. Afin que les contributions puissent être versées entièrement aux destinataires, nous avons pris la décision de renoncer à l'envoi de lettres de remerciement pour les dons inférieurs à 500 francs. Nous espérons que les donateurs feront preuve de compréhension et nous leur adressons encore une fois nos remerciements.

Le trésorier du Conseil de fondation
Zürcher Hochschule für Angewandte Wissenschaften

\section{Quelle recherche pour la physiothérapie} en Suisse ?

Votre opinion de médecin sur les besoins futurs dans le domaine de la recherche en physiothérapie nous intéresse - c'est vous qui pourrez nous aider dans la définition des thématiques importantes. En effet, c'est dans le cadre d'une étude menée sur le sujet de l'état de la recherche en physiothérapie par une équipe de chercheurs des quatres Hautes Ecoles de Santé de Suisse que nous souhaitons intégrer les avis de différents groupes professionnels collaborants avec les physiothérapeutes sur le sujet des futures priorités de recherche.

Notre prochaine étape consiste en février et en mars 2012 à vous consulter par Internet afin de vous donner la possibilité de revoir/ évaluer les thématiques élaborées par la phase précédente de l'étude et recueillies lors des focus groupes comprenant au total l'avis de 135 personnes. Cette enquête en ligne sera réalisée en français, en allemand et en italien. Désirez-vous participer activement à l'élaboration des futures orientations en recherche physiothérapeutique? Si tel est le cas, nous vous remercions de communiquer votre adresse e-mail à: irina.nast[at]zhaw.ch 